entomologists. In addition to much greater facility in capturing, transporting, feeding and keeping them moist, the ants are placed under much more natural conditions and may be expected to show more normal behavior.

Washington, D. C., O. F. Coor.

$$
\text { August 17, } 1904 .
$$

\section{IMPORTANCE OF ISOLATED REARINGS FROM CULICID LARVA.}

THE fact that four, five or more species of larvæ occur in association in the same pool, renders it difficult to separate the various species, especially as living larvæ resemble each other very closely. Particular attention has been paid to this phase of the subject during the present season with very gratifying results, as may be seen from the following:

A larva somewhat resembling and associated with Culex impiger presents marked differences in that the dorsal surface of the air tube is provided with a double row of hairs, each row consisting of about four tufts composed of a pair of weakly barbuled hairs. This is undoubtedly the larva which Messrs. Dyar and Knab* have confused with that of Culex impiger. From this larva a large, brownishgray mosquito 6 to $7 \mathrm{~mm}$. long, with the curved scales of the head white, was obtained. This species has been given the name of Culex cinereoborealis $\mathrm{n}$. $\mathrm{sp}$.

A larva somewhat resembling that of $C$. impiger was met with in a cold mountain pool at Elizabethtown, N. Y., June 9, adults emerging on the tenth and closely resembling those of $C$. impiger. The larva may be easily recognized by the conspicuous, triangular comb composed of about sixty rather large scales, each tipped with from four to seven stout, equal spines. The air tube is short, a little over twice as long as broad, slightly swollen at the basal third and bearing a double row of pasterior pecten, each consisting of about twenty short, black, stout spines. The adult, Culex lazarensis n. sp., may be distinguished from C. impiger by its large size, it being 6 to $7 \mathrm{~mm}$. long, and the vittate thorax with two dark lines. The wing of the female $C$. lazarensis is longer, the second longitudinal

*Ent. Soc. Wash. Proc., 6: 144, 1904. vein, particularly at its fork, is straighter, and the second fork cell is shorter and broader than in C. impiger. There are also marked differences in the male genitalia.

Another very interesting larva was met with June 14 in a cold mountain pool at Elizabethtown, N. Y., and may be easily recognized by the comb consisting of but six to seven thornlike scales arranged in a curved line, with a large, finely setose, spatulate base and with a stout, apical spine. The air tube is about three times as long as wide, tapering regularly and with double posterior pecten on the basal third, each row consisting of twelve to fifteen closely set, stout spines, each bearing near the basal third one large and usually a smaller tooth. This larva produced an adult, Culex abserratus n. sp., which resembles $C$. impiger very closely and may be separated therefrom by the posterior cross vein being its own length or more from the mid cross vein, the thorax spotless, basal abdominal bands distinct, and the petiole of the first submarginal cell one half the length of the cell.

A long-tubed larva with a comb consisting of about eighteen triangular, stout, spined scales arranged in two or more rows, some of the scales having a very stout, terminal spine with smaller ones along each side, while others have the tips somewhat rounded and the spines more nearly of a size, was taken in a woodland pool at Karner, on May 10, adults emerging on the sixteenth. The air tube is fully five times as long as its greatest diameter, tapering somewhat regularly and with a slight bend and contraction near the middle. There are two rows of pecten, each consisting of about twenty-two closely-set teeth bearing at their bases usually two larger and three or four fine serrations. This species, Culex fitchii n. sp., is close to Culex squamiger Coq., and may be separated therefrom by the scales of the pleura being white and the posterior cross vein its own length from the one above. The basal segments of the antennæ are clothed interiorly with broad white scales; proboscis dark-brown, long; palpi dark brown, segments narrowly ringed at the base with white; occiput clothed with brown scales, with a row of silvery ones just above the eyes and 
along the median line. Thorax with a broad, brown, central stripe bordered with a rather well-defined silvery, slightly broader, lateral stripe containing a few brown blotches. Pleura rather thickly clothed with patches of silvery white scales.

These species will be characterized more fully in a Bulletin of the New York State Museum soon to be issued.

\section{E. P. FeLt,} D. B. Young.

\section{NOTES ON SOCIAL AND ECONOMIC SCIENCE.}

AGRICULTURAL ECONOMICS.

INTEREST in agriculture, like that in commerce and industry, tends more and more to take upon itself an international character. The correlation of international experience and the comparison of experiments, tendencies and economic conditions is one of the most fruitful fields of research, not only to the economist, but equally so to the technical agriculturist and to the practical farmer. Consumers generally are interested to the extent to which prices are affected by the favorable or unfavorable harvests in any particular country or group of countries. Any country whose system of production or distribution remains too far behind in the progress of scientific and practical economics must sooner or later lose its capacity to compete in the world market. The same is true of any particular crop, unless it be favored by special natural advantages. Just at this time much attention is being given to the study of the comparative strength of nations and the leading national systems of productive efficiency. It is hoped, therefore, that the following more or less specific accounts of agricultural conditions in the several countries represented may be deemed of timely interest and value.

\section{SCIENTIFIC AGRICULTURE IN JAPAN.}

A RECENTLY returned. writer from the far east calls attention to the fact which students of oriental civilizations have so long overlooked, namely, the extent to which the Japanese especially have accepted the truth that the natural sciences lie at the basis of the material development of nations. In its own way Japanese husbandry seems to have worked out much that the experiment station has accomplished in the west. This writer (Mr. Harold Bolce, in Booklover's Magazine) calls the Japanese, with their 19,000 square miles of arable land, the most remarkable agricultural nation the world has known. "If all the tillable acres of Japan were merged into one field," he says, "a man in an automobile, traveling at the rate of fifty miles an hour, could skirt the entire perimeter of arable Japan in eleven hours. Upon this narrow freehold Japan has reared a nation of imperial power, which is determined to enjoy commercial preeminence over the world of wealth and opportunity from Siberia to Siam, and already, by force of arms, is driving from the shores of Asia the greatest monarchy of Europe.

"The secret of the success of the little Daybreak Kingdom has been a mystery to many students of nations. Patriotism does not explain the riddle of its strength, neither can commerce; nor military equipment nor manufacturing skill. Western nations will fail fully to grasp the secret of the dynamic intensity of Japan to-day, and will dangerously underestimate the formidable possibilities of the Greater Japan (the Dai Nippon) of tomorrow, until they begin to study seriously the agricultural triumphs of that empire. For Japan, more scientifically than any other nation, past or present, has perfected the art of sending the roots of its civilization enduringly into the soil.

"Progressive experts of high authority throughout the orient now admit that in all the annals of agriculture there is nothing that ever approached the scientific skill of Sunrise husbandry. Patient diligence, with knowledge of the chemistry of soil and the physiology of plants, have yielded results that have astounded the most advanced agriculturists in western nations."

CHANGES IN BRITISH AGRICULTURAL POLICY.

THE progress of scientific agriculture in England increasingly takes the form of assistance in effecting the adaptation of the industry to such crops as do not compete with 